„Bohemistyka” 2021, nr 3, ISSN 1642-9893

Jana RACLAVSKÁ

Jiří MURYC

Ostravská univerzita

\section{Bohemizmy w polskich kazaniach ze Śląska Cieszyńskiego z przelomu XVIII i XIX wieku}

Keywords: language contacts, Bohemisms, sermons, Śląsk Cieszyński, Polish, Czech, regional variety of Polish

Słowa kluczowe: kontakty językowe, bohemizmy, kazania, Śląsk Cieszyński, język polski, język czeski, regionalny wariant polszczyzny

\section{Abstract}

The mutual influences of Polish and Czech have been the subject of much research. Both of these West Slavic languages have similar developments not only in phonetics and morphology, but also in lexis. The separation of Bohemisms from the Polish language is very difficult from today's point of view. The discovery of borrowings from Czech has already been the subject of research by many Polish and Czech linguists (A. Brückner, T. Lehr-Spławiński, S. Rospond, Z Orłoś, B. Havránek, J. Damborský, etc.). In this study we try to determine the degree of influence of the Czech language on the regional variant of the Polish language of Těšín at the end of the 18th and the first half of the 19th century. As research material we used manuscripts of sermons of Protestant clergymen (15 manuscript texts in total). We performed their linguistic analysis and revealed a total of 43 units that could be clearly identified as Bohemisms. It was found that the proportion of Bohemisms in the examined texts was not significant and the forms used were found in common communication in dialect.

Vzájemné vlivy polštiny a češtiny jsou předmětem mnoha výzkumů. Oba tyto západoslovanské jazyky mají podobný vývoj nejen v oblasti fonetiky a morfologie, ale také $\mathrm{i}$ lexiky. Vydělení bohemizmů $\mathrm{z}$ polského jazyka je $\mathrm{z}$ dnešního hlediska značně složité. Odhalení výpůjček z češtiny bylo již předmětem zkoumání mnoh polských i českých jazykovědců (A. Brückner, T. Lehr-Spławiński, S. Rospond, Z. Orłoś, B. Havránek, J. Damborský aj.). V této studii se snažíme o zjištění stupně vlivu českého jazyka na regionální variantu těšínské polštiny konce 18. a první poloviny 19 . století. Jako výzkumný materiál jsme použili rukopisy kázání protestantských duchovních (celkem 15 rukopisných textů). Provedli jsme jejich jazykovou analýzu a odhalili celkem 43 jednotek, které bylo možné jednoznačně označit jako bohemizmy. Bylo zjištěno, že podíl bohemizmů ve zkoumaných textech není významný a použité formy se vyskytovaly $\mathrm{v}$ běžné nářeční komunikaci.

Uwaga, jaka poświęcana jest stosunkom polsko-czeskim, nie dziwi z wielu względów. Na pierwszym miejscu zazwyczaj przywołuje się bliskość geograficzną i z nią związane kontakty i konflikty. Od dawna również wzbudzają zainteresowanie zagadnienia wzajemnych wpływów językowych i to zarówno z perspektywy historycznej, jak również w sytuacji obecnej zwłaszcza na terenach przygranicznych. Wpływy języka czeskiego na polszczyznę literacką badało wielu wybitnych językoznawców zarówno czeskich, jak i polskich, np. B. Havránek, J. Damborský, W. Nehring, A. Brückner, T. Lehr-Spławiński, W. Taszycki, S. Urbańczyk, S. Rospond, Z. T. Orłoś i in. Okres, kiedy polszczyzna poddana była wpływowi języka czeskiego, był stosunkowo długi i przebiegał, jak pisze Teresa Zofia Orłoś, w trzech falach. Pierwszy okres to wczesne średniowiecze łączące się ze znamiennym faktem w historii Polski - przyjęciem chrześcijaństwa za pośrednictwem czeskim. Wtedy to polszczyzna wzbogacona została zwłaszcza o terminologię religijną (Orłoś 1997, s. 9-10).

Następna fala bohemizmów przeniknęła do języka polskiego w XIV i XV wieku, kiedy w Czechach nastały przyjazne warunki do rozwoju kultury i nauki i z tym związany rozkwit języka czeskiego. To z kolei spowodowało przedostawanie się czechizmów do polskich tekstów pisanych (Orłoś 1997, s. 10). Założenie w roku 1348 w Pradze pierwszego uniwersytetu w Europie Środkowej przyciągnęło tam wielu Polaków, późniejszych wykładowców Akademii Krakowskiej, którzy zdobyli tam znajomość czeszczyzny. Wspomniana T. Z. Orłoś pisze:

Na przełomie XIX i XV w. czeszczyzna była uważana za „lepszy” język, pełniła nawet na dworze królowej Jadwigi i Jagiełły funkcję języka dworskiego (Orłoś 1997 s. 11)

Burzliwy okres wojen husyckich również odbił swoje piętno w języku Polaków. Wielu z nich wspierało dążenia husytów skierowane 
na reformy w życiu religijnym i społecznym. Przedstawiciele obu narodów - Czesi i Polacy - spotykali się w tym czasie głównie na polach walki, stąd pojawianie się bohemizmów w polszczyźnie zwłaszcza w zakresie terminologii wojskowej, np. hasło, hetman, puszka itp. (Orłoś 1997, s. 11).

Trzecią falę bohemizmów odnotowujemy w pierwszej połowie XVI wieku, kiedy na tereny polskie przedostają się czeskie tłumaczenia dzieł religijnych powstałych w kręgu braci czeskich. Znajomość czeszczyzny na dworze zygmuntowskim uważana była za znamię przynależności do warstw elitarnych (Orłoś 1980, s. 20). O popularności języka czeskiego i jego wpływie na polszczyznę okresu renesansu świadczą licznie występujące bohemizmy w thumaczeniach dzieł religijnych oraz literaturze świeckiej. Znani z częstego używania czechizmów byli m. in.: Marcin Bielski, Jan z Koszyczek, Mikołaj Rej czy Jan Sandecki-Malecki. Roli języka czeskiego i jego wpływu na polszczyznę tego okresu nie należy jednak przeceniać. W kontekście powyższych danych warto przytoczyć stwierdzenie Mieczysława Basaja analizujacego teksty Marcina Krowickiego, szesnastowiecznego pisarza reprezentującego krąg innowierców. Autor ten potwierdza występowanie bohemizmów w jego tekstach, lecz nie sądzi, by przekraczały one normę, twierdzi, że użycie bohemizów u badanego pisarza odpowiada niejako stanowi panującemu w ówczesnej polszczyźnie. Basaj nie odnotowuje takiego nasilenia wpływu języka czeskiego u Krowickiego jak np. u Reja, ale przyznaje, że Krowicki korzystał z zasobów bohemizmów już wcześniej w polszczyźnie zadomowionych (Basaj 1966, s. 198-200).

Od drugiej połowy XVI wieku obserwujemy osłabienie wpływu języka czeskiego na polszczyznę. Dzieje się tak dzięki rozwojowi piśmiennictwa polskiego i stabilizacji polskiego języka literackiego w wieku XVII, co jest zasługa pisarzy okresu renesansu, zwłaszcza zaś Jana Kochanowskiego (Orłoś 1980, s. 23). Polszczyzna tego okresu pełni funkcję języka artystycznego, powstają oryginalne dzieła, nie zaś wyłącznie przeróbki i przekłady autorów obcych.

Wpływy języka czeskiego na polszczyznę w ciagu historii nie odnotowujemy jedynie w zakresie ogólnopolskiego języka literackie- go. Warto również przyjrzeć się tekstom powstałym na pograniczu językowym czesko-polskim, gdzie na co dzień spotykali się i spotykają nadal przedstawiciele obu narodów. Tereny Księstwa Cieszyńskiego od połowy XIV wieku były lennem królów czeskich, nic więc dziwnego, że czeszczyzna przedostawała się już od pierwszej połowy $\mathrm{XV}$ w. do kancelarii książąt cieszyńskich, wypierajac $\mathrm{z}$ nich stopniowo język niemiecki i łaciński (Panic 2016, s. 30), a w pierwszej połowie XVI wieku język czeski stał się językiem urzędowym na szerszych terenach Śląska. Ówczesna fascynacja kulturalną czeszczyzną okresu humanizmu (konkretnie językiem Biblii Kralickiej) była zrozumiała ze względu na fakt, że czeski język miał już w tym czasie o wiele lepiej wykreowaną normę literacką niż język polski.

Używanie czeszczyzny na Śląsku Cieszyńskim (nie tylko w kancelariach, ale też np. przez Jerzego Trzanowskiego, 1592-1637) nie świadczy o umocnieniu się elementu czeskiego ludności miejscowej, lecz jest zjawiskiem bardziej ogólnym. Zresztą „u schyłku średniowiecza także w Królestwie Polskim rozważano wprowadzenie języka czeskiego do kancelarii królewskiej" (Panic 2016, s. 30). Język czeski, jak dokumentują niektóre zabytki piśmienne (Raclavská 2001, s. 107-110), obsługiwał na terenie Śląska Cieszyńskiego tylko sferę oficjalną, język codzienny różnił się od tego używanego w urzędach i kościele. Kiedy więc książęta cieszyńscy ogłosili w r. 1584 tzw. Porządek szkolny, na podstawie którego poddani mieli przywilej posyłania swoich dzieci na naukę do szkół przykościelnych, gdzie nauczano w języku ojczystym, była to mowa polska (Kadłubiec 1994, s. 8-9). W ten sposób mogła przeniknąć do czytelników cieszyńskich Postylla domowa Marcina Lutra wydana w Królewcu w roku 1574 czy Postylla Samuela Dambrowskiego. Znane też były dzieła Jana Kochanowskiego i Mikołaja Reja.

Wiek XVII przerwał ten stan, przyniósł ze sobą wojny, rabunki i restrykcje natury wyznaniowej. Dopiero cześciowe przyznanie praw protestantom związane z umową altransztacką w r. $1707^{1}$ wywołało

${ }^{1}$ Wydarzenie to związane było z wyprawą wojenną króla szwedzkiego Karola XII w $1706 \mathrm{r}$. Władca ten po zwycięskim marszu przez ziemie polskie wtargnął do 
w Cieszyńskiem aktywizację polskiego życia kulturalnego, nie tylko ewangelickiego, lecz również katolickiego. Sprowadzeni do Cieszyna w pierwszej połowie XVIII wieku pastorowie ewangeliccy stwierdzili, że ludność tutejsza potrzebuje książek nabożnych pisanych w znanym jej języku. Wtedy zasługą Jana Muthmana i Samuela Ludwika Zasadiusa, wychowanków centrum ewangelickiego w Byczynie (Broda 1972, s. 9), powstają pierwsze teksty pisane w języku polskim, określanym później jako regionalny wariant polszczyzny cieszyńskiej (Raclavská 2012, s. 315-323). Książki Muthmana i Zasadiusa zaczęły wypierać kancjonały, postylle i modlitewniki czeskie. Ponadto duszpasterze ci wychowali swoich następców, którzy podobnie jak i oni czuli potrzebę twórczości w języku polskim (Hierowski, Rospond 1948, s. 15-16). Polskie piśmiennictwo katolickie na całym Śląsku nie było w owym czasie tak liczne jak protestanckie. Polskie książki najczęściej sprowadzano z Krakowa, ale przywozili je też duchowni powoływani do tutejszych parafii (Gumuła 1992, s. 22). Pomimo tego księża katoliccy Jan Judasz Hackenberg, Jerzy Bajtek i Franciszek Knöbel zareagowali na potrzeby duchowe cieszyńskiego społeczeństwa katolickiego i napisali książkę, będącą w znacznej części tłumaczeniem z języka niemieckiego, ale - jak piszą w Przedmowie do czytelnika - „twojemu jenzykowi, a mowie w druku przyspusobiona”. Książka ta wyszła w Opawie w roku 1761. Tutaj należy wspomnieć, że książki wydawane w oficynach polskich w tym czasie były już drukowane czcionką łacińską, a cieszyńskie czcionką gotycką (szwabachą) używaną w monarchii habsburskiej. Oznaczało to dla cieszyńskiego czytelnika znaczne utrudnienie odbioru współczesnych dzieł literatury polskiej.

Stosunkowo spokojny i owocny okres przerwały tzw. wojny śląskie (1740-1763) prowadzone przez cesarzową Marię Teresę z kró-

Saksonii, gdzie zmusił ówczesnego króla polskiego i elektora saskiego Augusta II do rokowań. Przy tej okazji odbyły się też rozmowy z cesarzem Józefem II, który zgodził się na podpisanie tzw. recesu egzekucyjnego, dodatku do umowy altransztackiej, na podstawie którego zwrócono ślaskim protestantom 128 kościołów i pozwolono na budowę sześciu nowych, tzw. kościołów łaski (Popiołek 1976, s. 95) lem pruskim Fryderykiem II, w wyniku których straciła ona wielką cześść Śląska. Pozostał w ramach monarchii habsburskiej tylko Śląsk Cieszyński (zwany Austriackim lub Wschodnim) i Śląsk Opawski (czyli Zachodni). Po 1782 r. dochodzi do podziału administracyjnego Monarchii Habsburskiej i Śląsk Cieszyński staje się częścią Gubernium Morawsko-Śląskiego ze stolicą w Brnie (1783-1849), nasila się wtedy wpływ języka czeskiego w sferze urzędowej.

$\mathrm{Na}$ dalszy rozwój ewangelickiego życia religijnego i związanego z nim używania polszczyzny w sferze kościelnej miał wpływ patent tolerancyjny wydany w roku 1781. Zezwolił on na odprawianie publicznych nabożeństw ewangelickich i zrównał prawa innowierców $\mathrm{z}$ katolikami. Powstały więc nowe gminy ewangelickie m.in. w Błędowicach, w Ligotce Kameralnej, w Bystrzycy i w Nawsiu. Działalność duszpasterzy ewangelickich miała niebywałe znaczenie w rozwoju świadomości narodowej mieszkańców Śląska Cieszyńskiego. Chodziło przede wszystkim o spełnienie postulatu głoszenia Słowa Bożego w języku zrozumiałym dla szerokich mas. Nie wystarczało, by tylko książki były pisane po polsku, do znacznie większej liczby słuchaczy docierało słowo mówione, dlatego homilie wygłaszane w języku polskim były obowiązkiem, co zaświadczaja zachowane do dziś zbiory kazań pastorów cieszyńskich. Wielu kaznodziejów nie pochodziło z Cieszyńskiego, ale opanowało język tutejszego ludu do tego stopnia, by móc wygłaszać mowy.

W Muzeum Protestantyzmu - Bibliotece i Archiwum im. Bogumiła Rudolfa Tschammera w Cieszynie znajdują się bogate zbiory rękopisów kazań. Najstarsze z nich pochodzą z połowy XVIII wieku. Wśród tekstów złożonych w Muzeum odnajdujemy kazania Jana Traugotta Bartelmusa, Józefa Franciszka Schimki, Jerzego Filipka, Jana Winklera, Wilhelma Raschkego, Karola Michejdy, Jerzego Heczki i in. Treść kazań najczęściej odnosi się do wydarzeń roku kościelnego, ale w zbiorach znajdują się też kazania pogrzebowe, rocznicowe, wspomnieniowe, instalacyjne. Pomimo tego że wszystkie odznaczają się wysokim stopniem opanowania języka polskiego przez piszacych, odnajdujemy w nich elementy typowe dla języka ludności cieszyńskiej oraz bohemizmy, które przeniknęły z języka urzędowego 
lub rodzimego kaznodziejów. Występowanie elementów innojęzycznych w polszczyźnie cieszyńskiej nie jest niczym wyjątkowym. W ciągu XVIII wieku w różnych regionach kraju odnotowane są procesy przejmowania elementów obcych lub gwarowych, nawet w języku literackim w owym czasie możemy odnaleźć rozmaite cechy regionalne (Bajerowa 1964, s. 201). Teksty cieszyńskie, które poddano analizie, pochodziły od następujących duchownych: Jana Traugotta Bartelmusa, Józefa Franciszka Schimki, Jerzego Filipka, Andrzeja Źlika, Jana Winklera oraz Wilhelma Raschkego. Wszyscy wymienieni duszpasterze z wyjątkiem Jana Winklera pochodzili ze Śląska Cieszyńskiego, czyli znali i posługiwali się miejscową gwarą, uczęszczali do gimnazjum ewangelickiego w Cieszynie, później studiowali na uczelniach w Lipsku, Wittenberdze i Wiedniu.

Zadanie, którego się podjęliśmy, polegało na wskazaniu czeskich elementów leksykalnych w tekstach polskich kazań, czyli wyrazów rodzimych czeskich i elementów dialektalnych, które zostały użyte przez duchownych pod wpływem ich bliskości do języka czeskiego (Basaj 1966, s. 13). Leksemy określone jako bohemizmy weryfikowano na podstawie Stownika języka polskiego S. B. Lindego (Linde 1807-1814), jednostek zawartych w publikacji M. Basaja: Bohemizmy w języku pism Marcina Krowickiego (Basaj 1966), słownika M. Basaja i J. Siatkowskiego: Bohemizmy w jezyku polskim (Basaj, Siatkowski 2006) oraz Stownika gwarowego Śląska Cieszyńskiego pod red. J. Wronicz (Stownik gwarowy 2010).

Najstarszy zbiór kazań pochodzi od kaznodziei Jana Traugotta Bartelmusa zajmującego wśród ewangelickich duchownych cieszyńskich jedno z czołowych miejsc, po pierwsze ze względu na swoją działalność w funkcji superintendenta morawsko-śląsko-galicyjskie$\mathrm{go}^{2}$, po drugie ze względu na obszerną spuściznę homiletyczną, która zachowała się do dziś, zebrana w pięciu tomach i złożona w Muzeum Protestantyzmu - Bibliotece i Archiwum im. B. R. Tschammera

\footnotetext{
${ }^{2}$ Superintendent to osoba wykonująca nadzór nad działalnością pastorów w kościele ewangelickim. Do jego kompetencji należało $\mathrm{m}$. in. przeprowadzanie wizytacji kościelnych i nadzoru nad szkolnictwem ewangelickim.
}

w Cieszynie. Kazania, które analizujemy dla potrzeb niniejszego opracowania, powstały w latach 1758-1809. Badania tekstów kazań wykazały, że najczęściej używane przez autora jednostki będące bohemizmami to: pozorny 'wnikliwy' (czes. pozorný): pozornego godne sq uwažania; z nienazdania 'nieoczekiwanie' (czes. z nenadáni): ižeć ie ogarnia z nienazdania; oswobodźit 'wyzwolił' (czes. osvoboditi); trawili 'spędzali' (czes. tráviti); spoieni 'złączeni' (czes. spojeni); stužby woienskiey 'służby wojskowej' (czes. služby vojenské); dać pozor 'uważać' (czes. dát pozor); od Krystusa odwiedl 'od Chrystusa odprowadził' (czes. od Krista odvedl); w stanie manželskim 'w stanie małżeńskim' (czes. ve stavu manželském). Niektóre leksemy, choć występowały w polszczyźnie, to jednak są przejęte z języka czeskiego, np. leksem naśladuiący 'następujący' (czes. následujici): naśladuiacy wiersz, jest przejęty prawdopodobnie $\mathrm{z}$ czeskiego, chociaż polszczyzna siedemnastowieczna ma go w swoim zasobie w tym samym znaczeniu. Podobnie może być z wyrazami: przeświadczyć 'przekonać' (czes. presvědčiti); przyležytość 'okazja' (czes. př́ležitost) i zakon 'prawo' (czes. zákon): chce nas przeświadczyć; dawa tež inszym przyležytość; zakon Božy. Natomiast leksem kamraci u Bartelmusa może być przejęty zarówno z czeskiego (kamarád), jako pożyczka pośrednia francuska camarade ,společnost dobrých přátel, druhư" (por. Váchek 1968, s. 237), lub z niemieckiego Kamerad <camera „co w tej samej komorze żyli” (Brückner 1970, s. 215), choć bardziej prawdopodobna jest tu pożyczka czeska.

Dalszy pokaźny zbiór tekstów rękopiśmiennych pochodzi od pastora Józefa Schimki, kaznodziei urodzonego we Vsetínie, ale żyjącego od dzieciństwa w Cieszynie. Jeśli chodzi o zasób słowny jego homilii, to zauważalny jest w nich zarówno wpływ gwary miejscowej, jak i języka czeskiego. Leksemy związane z podłożem gwarowym maja pochodzenie staropolskie, lecz wystepuja również w ówczesnym języku czeskim. Nie mamy więc pewności, że w danym konkretnym przypadku chodzi o element gwarowy czy czeski. Zwłaszcza w wypadku, że chodzi o człowieka, który, być może, używał na co dzień języka czeskiego. Do powyższej grupy należą np. formy: przyleżytość 'okazja' (czes. príležitost), obleczenie 'ubranie' (czes. Oble- 
čeni), trapić 'męczyć' (czes. trápiti), spojony 'połączony' (czes. spojený), odeprzit 'odmówić sobie' (czes. odepríti si): wiele radości sobie odeprził; wynaszat się 'wywyższał się' (czes. vynášeti se): nad ktorymi się wynaszat 'nad którymi się wywyższał'. Do bohemizmów zaś zaliczymy: opatrzanie 'ochrona' (czes. opatrováni $)$ : $w[\ldots]$ opatrzaniu całego świata; uprzymność 'szczerość' (czes. upř́mnost), ctność 'cnota' (czes. cnost), požegnanie 'błogosławieństwo' (czes. Požehnáni): požegnanie dat dziecięciu; uiszczony 'upewniony' (czes. Ujištěný): byt uiszczony 'był zapewniony' (czes. byti ujištěn); naiwięc 'najwięcej' (czes. nejvic): trzy rzeczy naiwięc cięžkim [...] czynia odeiście; pozustawać 'składać się z czegoś' (czes. pozůstavat): człowiek z dwóch części pozustawa; zawisi 'jest zależny od czegoś/kogoś' (czes. závisi): człowiek zawisi na rzeczach cielesnych; przeświadczony 'przekonany' (czes. presvědčený): on przeświadczony iest; kazić 'psuć' (czes. kazit): inaczey by się natura kaziła; odwadzać 'odwracać uwagę' (czes. odvádět): odwadza nas od [...] miłości świata. Użycie słowa zakon 'prawo' (czes. zákon): według zakonu Moyžeszowego w tym wypadku przypisujemy również wpływowi języka czeskiego.

W zbiorze polskich kazań zalazł się również tekst z roku 1839 księdza Jerzego Filipka. Rozpoczął on swoją pracę duszpasterska w 1828 roku w Jaworzu, gdzie służył 8 lat. W roku 1837 przeniósł się do Ligotki Kameralnej. Tam wygłosił mowe pt. Kazanie ktore trzymał przy Insztalacyi swey a Wizytacyi kościelney Jerzy Filipek kaznodziea zboru Ligockiego, dnia 11 Czerwca 1839, będaca przedmiotem naszej analizy. W wypadku powyższego tekstu zauważamy mniejsze uzależnienie od wzorów przejętych $\mathrm{z}$ dawnych tekstów polskich i tak samo mniejszą liczbę bohemizmów niż u jego poprzedników. Do bohemizmów zaliczyć możemy: przeświadczenie 'przekonanie' (czes. přesvědčeni); pieczuiąc 'opiekując się' (czes. pečujic); przednieść ‘wypowiedzieć, wyłożyć' (czes. prednésti); almužna 'jałmużna' (czes. almužna); list 'listek' (czes. list); przecz 'przecież' (czes. prec): przecz každy rozumny uznać musi.

Autorem kolejnego analizowanego tu kazania jest Andrzej Źlik urodzony w Kozakowicach, absolwent gimnazjum ewangelickiego w Cieszynie i studiów teologicznych w Wiedniu. Swoją działalność duszpasterską rozpoczął w Ramsau w Styrii, gdzie przebywał w latach 1824-1829, później pełnił służbę w Starym Bielsku, a od roku 1835 był pastorem w Cieszynie. Z tego roku zachował się rękopis jego kazania wygłoszonego z okazji śmierci cesarza Franciszka I. Słownictwo kazania Andrzeja Źlika bogate jest w archaizmy, dialektyzmy i bohemizmy. Jak już powyżej sygnalizowano, problemem okazuje się wydzielenie bohemizmów z archaicznej warstwy leksykalnej polskiej, ponieważ ,znaczna część wyrazów staropolskich [...] zachowała się do dziś w gwarach cieszyńskich" (Wronicz 1983, s. 180). Karol Daniel Kadłubiec uwazą, że zjawiska występujące w staropolszczyźnie, a obecne dziś w języku czeskim, należy oceniać w ramach całego systemu:

Nie sa one bohemizmami, ale integralnymi składnikami owego systemu gwarowego, w którym się całkowicie mieszczą, tworząc wraz z innymi jego spójny staropolski obraz (Kadłubiec 2015, s. 102).

Dotyczy to zwłaszcza tych tekstów, których autorami są ludzie pochodzący ze Śląska Cieszyńskiego lub tutaj zadomowieni, a takim był na pewno Andrzej Źlik. Archaizmy polskie będące składnikami cieszyńskiej leksyki gwarowej spotykamy w analizowanym kazaniu niemalże we wszystkich planach językowych, np. fonetycznym: inszy; tydnie, dzisia, słowotwórczym: zdało się 'wydawało się', przystęp 'dostęp', przypuszczać 'dopuszczać', dozwolenie 'pozwolenie', okazować 'pokazywać', uważać 'poważać', czuć 'czuwać', leksykalnym: prawidło 'zasada', fundować 'zakładać', forytować 'popierać', nazdawać się 'przewidywać', sławność 'uroczystość', stusznie 'odpowiednio'. W tekście tym znajdują się również liczne bohemizmy: prawidto 'zasada' (czes. pravidlo), truchliwy 'zatrwożony' (czes. Truchlivý), spolegać 'polegać' (czes. spoléhat) oraz połączenia wyrazowe: te słowa płaca Krolowi Dawidowi 'te słowa odnoszą się do króla Dawida' (czes. ta slova platí pro krále Davida); hojna miara 'w obfitości' (czes. hojnou měrou); ̇̇e znaczna suma jej ... na pomocy być raczyt 'że znaczną sumą ją wspomagał' (czes. že značnou částkou ráčil jí být nápomocen). 
Interesująco przedstawia się warstwa leksyki i frazeologii kazań duszpasterza Wilhlema Raschkego. Częściej niż inni kaznodzieje cieszyńscy korzysta on z zasobów staropolskich i gwarowych. Odnotowujemy wiele archaizmów polskich w różnych planach językowych, np. dzisia 'dziś', sumnienie, wyćwika, przytomni 'obecni', nazadź 'do tyłu', smętek. Trudno jednak o jednoznaczna odpowiedź, skąd wzięły się u Raschkego formy, występujące w dawnej polszczyźnie i w ówczesnej czeszczyźnie, takie jak: to o nas płaciło 'to nas dotyczyło' (czes. to platilo o nás), jaka być nie śmie ‘jaka nie może być' (czes. jaká nesmí být), nie stoi o radość wasza 'nie zależy mu na waszej radości' (czes. nestojí o vaši radost), radzi przychodźcie 'chętnie przychodźcie’ (czes. rádi přicházejte). Z podłoża gwarowego do kazań przeniknęły jednostki, takie jak: ochotnie 'chętnie' (czes. ochotnè), dziwać 'patrzeć' (czes. divat se), wiele ich chybia 'wiele ich brakuje' (czes. mnoho jich chybi), naślady 'następstwa' (czes. následky): ktore sa naślady oney wyćwiki; które człowiekowi patrzy 'które należy się człowiekowi’ (czes. které člověku patři). Także powyżej podane jednostki gwarowe mają swoje odpowiedniki czeskie, jak podaliśmy w nawiasach. Bezpośredni zaś wpływ języka czeskiego na język jego kazań widać w takich leksemach, jak: szactwo 'odzież' (czes. šactvo); strom 'drzewo' (czes. strom); oswobodzenie ‘wyzwolenie' (czes. osvobozeni); przyimać (przyjmować, (czes. prijímat); z przeświadczenia 'z przekonania' (czes. z přesvědčeni); obce 'wioski' (czes. obec); odrzeknąć 'wyrzec się’ (czes. odříct si); przywiedzie 'przyprowadzi' (czes. privede).

Jan Winkler' ${ }^{3}$, pastor, którego językiem ojczystym był czeski, opanował biegle polszczyznę. Dzięki temu w jego mowach bohemizmy

${ }^{3}$ Jan Winkler - kaznodzieja, którego nazwisko kojarzone jest przede wszystkim ze zborem ewangelickim w Nawsiu koło Jabłokowa - urodził się w roku 1794 we Vestínie, gdzie uczęszczał do szkoły protestanckiej. Jego dalsza edukacja obejmowała naukę w gimnazjum w Trenczynie, Keżmaroku i węgierskim Szabolcsu. Studium teologii rozpoczął na Słowacji, a ukończył w Lipsku w roku 1820. Po studiach na krótko wrócił do Vsetína, a później objął posade po Józefie Franciszku Schimce w Nawsiu koło Jabłonkowa (200 let budovy Evangelické školy, on-line 2.09.2017) pojawiają się w tym samym stopniu, co u innych kaznodziejów pochodzacych z Śląska Cieszyńskiego. W swych tekstach korzysta on zarówno $\mathrm{z}$ archaizmów polskich na różnych poziomach języka, ze słownictwa gwarowego, jak i bohemizmów. Fakt ten nie wpływa jednak na komunikatywność kazań. Tradycyjnie używane przez pastorów cieszyńskich archaizmy, a występujące również u Winklera, to: wniść, chętliwy, dobrota 'dobroć', pachać 'czynić, popełniać', zdać się 'wydawać się', lutować, rozdziat 'różnica' (czes. rozdil): I tu wielki rozdział między ludźmi, zakon 'prawo'. Występująca w słowniku Lindego przyležytość 'okazja' (czes. přiležitost) u Winklera należy potraktować jako bohemizm niż polski archaizm. Bohemizmami natomiast są: podpora 'wsparcie' (czes. podpora): podpory [...] potrzebowali; uprzymnie 'szczerze' (czes. upř́mně), pieczować 'opiekować się' (czes. pečovat): pieczuiac tylko o źiemskie dobra; tykać 'dotyczyć' (czes. týkat se): co kolwiek się [...] rozumu i serca tykało, i frazeologizmy: nie wziąt ku sercu (czes. nevzal si k srdci) czy przyimuie grzesz. na miłość (czes. bere hř́šníka na milost).

$$
* * *
$$

Jak już wielokrotnie wzmiankowano, nie można dokładnie określić, jak duży był wpływ języka czeskiego na język kazań cieszyńskich. Wiele wyrazów przejętych do polszczyzny bezpośrednio z języka czeskiego lub za jego pośrednictwem z łaciny czy języka niemieckiego było w polszczyźnie już zadomowionych i funkcjonowało jako rodzime. Inne zaś wyszły z użycia i zachowały się jako archaizmy, występujace jeszcze w gwarach. W tym przypadku, w specyficznych warunkach Śląska Cieszyńskiego, można by użyć terminu Mieczysława Basaja (1966, s. 196) półbohemizm arbitrażowy na określenie form, które funkcjonują jeszcze w miejscowej gwarze, a równocześnie występują w języku czeskim, jak np.: zdać się-zdát se 'wydawać się', lutować - litovat 'żałować', prawidło - pravidlo 'zasada', sławność - slavnost 'uroczystość'.

Nie ulega jednak wątpliwości, że wpływ języka czeskiego na język dziewiętnastowiecznych kazań cieszyńskich jest faktem dokonanym, o czym świadczą analizowane powyżej teksty oraz wskazane bohe- 
mizmy. I mimo że jest ich niewiele (43 jednostki we wszystkich planach językowych od fonetycznych przez słowotwórcze, leksykalne, po frazeologiczne), to ukazują opisywane zjawisko w XIX wieku, tym samym dokumentując stan ówczesnej polszczyzny regionalnej Śląska Cieszyńskiego.

\section{Źródla}

B a rte lmus J. T., 1758, Kazanie na dzień św. Mateusza.

Bart e $1 \mathrm{~m}$ u s J. T., 1775, Parentacya trzymana dnia 10 Xbra 1775 Nieboszczyk. Jendrzeyiowi Sniegonowi.

B a r t e 1 m u s J. T., 1795, Sermo Installatorius Rev. Dni Christiani Raschke Pastoris Ecclesia Bludowicensis.

B a r t e $1 \mathrm{~m}$ u s J. T., 1795, Kazanie pamięteczne trzymane Nieb. Janowi Kubeczkowi Chatupnikowi z Gorn. Žukowa.

B artelmus J. T., 1786, Kazanie pogrzebne Nieboszcz. Zuzannie Chlebkowey $z$ Nieborow.

B a r te $1 \mathrm{~m}$ u s J. T., 1787, Kazanie pogrzebne trzymane dnia 28 Jan. 1787 Nieboszczykowi Jakubowi Lasotowi.

B a r t e $1 \mathrm{~m}$ u s J. T., 1787, Nieboszce wysoce szlachetnie urodzonej Pani Ewie Charloćie owdowiałej Radeckiey rodzonej Skrbenskiey z Hristie.

B a r t e $1 \mathrm{~m}$ u s J. T., 1790, Kazanie pamiateczne Nieb. Annie Nessytce owdowiatey, a umarley w Frysztaćie.

Bartelmus J. T., 1800, Kazanie pogrzebowe trzymane Janowi Kotasowi Mtodzieńcowi na Oldrzychowskim Cmętarzu dnia 18 Sierpnia.

F ili pe k J., 1839, Kazanie ktore trzymat przy Insztalacyi swey a Wizytacyi kościelney Jerzy Filipek kaznodziea zboru Ligockiego, dnia 11 Czerwca 1839.

R a s c h k e W., 1834, Oradości św. Chrześciana.

$\mathrm{R}$ a s c h ke W., 1848, Wyćwika Boża w naszym czasie.

$\mathrm{S} \mathrm{c}$ h i m k o J. F., 1822, Nie mamy nic drogszego nad wiare nasza...

W i n k l e r J., 1829, Chrześć. Kładzie to za powinność mitości braterskiey...

W in k 1 e r J., 1830, Wszystko co tu na tey ziemi, przemianom podlegle iest...

W in k le r J., 1831, Z radościa i z pociecha podnosimy serce nasze do Ciebie.

W i n k le r J., 1837, Poświęć nas o Bože, abysmy byli spusobni opowiadać chwate Twoia.

\section{Literatura}

B a jerowa I., 1964, Kształtowanie sie systemu polskiego języka literackiego w XVIII wieku. Wrocław-Warszawa-Kraków: Zakład Narodowy imienia Ossolińskich, Wydawnictwo Polskiej Akademii Nauk.
B a s a j M., 1966, Bohemizmy w jezyku pism Marcina Krowickiego. Wrocław-Warszawa-Kraków: Zakład Narodowy imienia Ossolińskich, Wydawnictwo Polskiej Akademii Nauk.

B ro da J., 1972, Udział pastorów w życiu kulturalno-narodowym Ślaska Cieszyńskiego w latach 1835-1865. Górki Wielkie [maszynopis].

H i e r o w s ki Z., R o s p ond S., 1948, Język i piśmiennictwo na Ślasku. Katowice-Wrocław: Wydawnictwa Instytutu Śląskiego. Polski Śląsk.

G u m u ł a U., 1992, Literatura polska na Ślasku w XVII i XVIII wieku. In: Wszechnica Górnoślaska VI. Oblicza literackie Śląska. Katowice-Opole-Cieszyn: Biblioteka Śląska, s. 17-39.

K a dłu bi e c K. D., 1994, Cieszyńsko-zaolziańska polszczyzna. Katowice: Wojewódzka Biblioteka Publiczna w Katowicach.

K a d ł u b i e c K. D., 2015, W cieszyńskim mateczniku, Czeski Cieszyn: Kongres Polaków w Republice Czeskiej.

L in d e S. B., 1807-1814, Stownik języka polskiego. T. 1-6, Warszawa: Drukarnia XX. Piiarów. Online: https://kpbc.umk.pl/dlibra/publication/88501/edition/ 93645 [dostęp: 10.05.2021]

Orłoś T. Z., 1980, Polsko-czeskie zwiazki językowe. Wrocław-Warszawa-Kraków-Gdańsk: Zakład Narodowy imienia Ossolińskich, Wydawnictwo Polskiej Akademii Nauk.

O rło ś T. Z., 1997, Wzajemne wphywy jezykowe czesko-polskie i ich uwarunkowanie historyczne. In: T. Z. Orłoś, J. Damborský (red.) Konsekwencje sasiedztwa polsko-czeskiego dla rozwoju języka i literatury. Polsko-české sousedstvi $v$ rozvoji jazyka a literatury. Wrocław: Ministerstwo Edukacji Narodowej RP, Uniwersytet Wrocławski, s. 9-21.

P a n i c I., 2016, Język mieszkańców Ślaska Cieszyńskiego od średniowiecza do polowy XIX wieku. Cieszyn: Polskie Towarzystwo Historyczne.

P o p i ołe k K., 1976, Slaqskie dzieje. Warszawa-Kraków: Państwowe Wydawnictwo Naukowe.

R a c l a v s ká J., 2001, Język zabytków urzędowych. In: J. Raclavská, Historia języka polskiego na Ślasku Cieszyńskim do roku 1848. Ostrava: Filozofická fakulta Ostravské univerzity, s. 107-110.

R a c l a v s ká J.,2012, Miejsce Drogi do Nieba Samuela Ludwika Zasadiusa w historii polszczyzny cieszyńskiej, „Studia Slavica” XVI, s. 315-323.

Słownik gwarowy Ślaska Cieszyńskiego, 2010, J. Wronicz (red.), Ustroń: Galeria „Na Gojach".

W ronic z J., 1983, Kształtowanie się cieszyńskiej odmiany języka literackiego, „Rocznik Cieszyński” IV/V, s. 172-182.

200 let budovy Evangelické školy v Návsí 1808-2008, 200 lat budynku Szkoły Ewangelickiej w Nawsiu 1808-2008. Online: http://enavsi.cz/wp-content/uploads/ 2015/07/200-let-skoly.pdf [dostęp: 10.05.2021] 